\title{
Lumen and calcium characteristics within calcified coronary lesions. Comparison of computed tomography coronary angiography versus intravascular ultrasound
}

Charakterystyka światła naczynia i zwapnienia w uwapnionych zmianach miażdżycowych w tętnicach wieńcowych. Porównanie tomografii komputerowej i ultrasonografii wewnątrznaczyniowej

\begin{abstract}
Dariusz Noll1', Mariusz Kruk², Jerzy Pręgowski³, Edyta Kaczmarska², Karolina Kryczka², Radosław Pracoń², Mirosław Skwarek², Zofia Dzielińska², Joanna Petryka², Mateusz Śpiewak², Barbara Lubiszewska²,

1Institute of Cardiology, Warsaw, Poland

${ }^{2}$ Coronary Disease and Structural Heart Diseases Department, Institute of Cardiology, Warsaw, Poland

3 Invasive Cardiology and Angiology Department, Institute of Cardiology, Warsaw, Poland
\end{abstract}

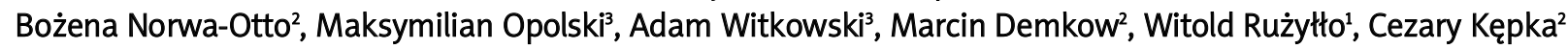

Postep Kardiol Inter 2013; 9, 1 (31): 1-8 DOI: $10.5114 /$ pwki.2013.34022

\begin{abstract}
Introduction: Computed tomography coronary angiography (CTCA) is a diagnostic method used for exclusion of coronary artery disease. However, lower accuracy of CTCA in assessment of calcified lesions is a significant factor impeding applicability of CTCA for assessment of coronary atherosclerosis.

Aim: To provide insight into lumen and calcium characteristics assessed with CTCA, we compared these parameters to the reference of intravascular ultrasound (IVUS).

Material and methods: Two hundred and fifty-two calcified lesions within 97 arteries of 60 patients (19 women, age $63 \pm 10$ years) underwent assessment with both $2 \times 64$ slice CT (Somatom Definition, Siemens) and IVUS (s5, Volcano Corp.). Coronary lumen and calcium dimensions within calcified lesions were assessed with CTCA and compared to the reference measurements made with IVUS.

Results: On average CTCA underestimated mean lumen diameter ( $2.8 \pm 0.7 \mathrm{~mm}$ vs. $2.9 \pm 0.8 \mathrm{~mm}$ for IVUS), lumen area (6.4 $\pm 3.4 \mathrm{~mm}^{2}$ vs. $7.0 \pm 3.7 \mathrm{~mm}^{2}$ for IVUS, $\left.p<0.001\right)$ and total calcium arc $\left(52 \pm 35^{\circ} \mathrm{vs} .83 \pm 54^{\circ}\right)$. However, analysis of tertiles of the examined parameters revealed that the mean lumen diameter, lumen area and calcium arc did not significantly differ between CTCA and IVUS within the smallest lumens ( $1^{\text {st }}$ tertile of mean lumen diameter at $2.1 \mathrm{~mm}$, and $1^{\text {st }}$ tertile of lumen area at $3.7 \mathrm{~mm}^{2}$ ) and lowest calcium arc (mean of $\left.40^{\circ}\right)$.

Conclusions: Although, on average, CTCA underestimates lumen diameter and area as well as calcium arc within calcified lesions, the differences are not significant within the smallest vessels and calcium arcs. The low diagnostic accuracy of CTCA within calcified lesions may be attributed to high variance and not to systematic error of measurements.
\end{abstract}

Key words: computed tomography, intravascular ultrasound, coronary angiography, coronary artery disease.

\section{Streszczenie}

Wstęp: Badanie tomografii komputerowej (TK) tętnic wieńcowych stosuje się w celu wykluczenia istotnych zwężeń w tętnicach wieńcowych. Niższa wartość diagnostyczna metody w ocenie zmian uwapnionych stanowi istotny czynnik ograniczający zastosowanie TK w ocenie osób z chorobą wieńcową.

Cel: Ocena charakterystyki światła naczynia i zwapnienia w TK w porównaniu z badaniem referencyjnym - ultrasonografią wewnątrznaczyniową (intravascular ultrasound - IVUS).

Materiał i metody: Przy użyciu 2 × 64-rzędowego TK (Somatom Definition, Siemens) i IVUS (s5, Volcano Corp.) oceniono 252 uwapnione zmiany miażdżycowe w 97 tętnicach u 60 chorych (19 kobiet, wiek $63 \pm 10$ lat). Wymiary światła naczynia i zwapnienia oceniono w miejscu minimalnego światła naczynia.

Corresponding author/Adres do korespondencji:

Mariusz Kruk MD, PhD, Coronary Disease and Structural Heart Diseases Department, Institute of Cardiology, 42 Alpejska St, 04-628 Warsaw, Poland, tel. +48 2234343 42, e-mail: mkruk@ikard.pl

Received: 27.9.2012, accepted: 11.10.2012. 
Wyniki: W całej grupie badanej w badaniu metodą TK uzyskano niedoszacowaną wartość średnicy naczynia $(2,8 \pm 0,7 \mathrm{~mm}$ vs 2,9 $\pm 0,8$ $\mathrm{mm}$ dla IVUS, $p<0,001)$, pola powierzchni światła $\left(6,4 \pm 3,4 \mathrm{~mm}^{2}\right.$ vs $7,0 \pm 3,7 \mathrm{~mm}^{2}$ dla IVUS, $\left.p<0,001\right)$ oraz tuku zwapnienia $\left(52 \pm 35^{\circ}\right.$ vs 83 $\pm 54^{\circ}$ dla IVUS, $\left.p<0,001\right)$. Jednak analiza tercyli badanych parametrów wykazała, że w obrębie naczyń o najmniejszej średnicy $(2,1 \mathrm{~mm})$, najmniejszym świetle $\left(3,7 \mathrm{~mm}^{2}\right)$ i z najmniejszym łukiem zwapnienia $\left(40^{\circ}\right)$ pomiary TK nie różnity się istotnie od pomiarów w IVUS.

Wnioski: W obrębie zmian uwapnionych w tętnicach wieńcowych w badaniu metodą TK uzyskuje się niedoszacowaną średnicę i pole światła naczynia oraz łuk zwapnienia, jednak różnica między pomiarami TK i IVUS jest nieznamienna w przypadku zmian o mniejszym świetle lub z mniejszym łukiem zwapnienia.

Słowa kluczowe: tomografia komputerowa, ultrasonografia wewnątrznaczyniowa, koronarografia, choroba wieńcowa.

\section{Introduction}

Computed tomography coronary angiography (CTCA) is currently used for exclusion of significant coronary stenoses. However, the high potential of the non-invasive assessment of coronary wall and lumen is currently underutilized due to current computed tomography (CT) technology limitations. One of the most significant constraints of CTCA remains its inaccuracy in assessing calcified lesions [1-6]. Since presence of coronary calcifications is synonymous with the presence of atherosclerosis, this limitation translates into lower accuracy of CTCA in assessment of atherosclerotic lesions or in more general terms patients with coronary artery disease.

Despite the fact that coronary calcium is one the main sources of diagnostic errors of CTCA, there is a paucity of data regarding this phenomenon.

\section{Aim}

Therefore, we compared calcium and lumen characteristics as assessed with CTCA to the reference images obtained with IVUS.

\section{Material and methods}

In a prospective, cross-sectional study, from June 2009 to January 2011, we enrolled 60 consecutive patients with suspected coronary artery disease. All patients underwent both CTCA and invasive angiography examinations for clinical indications. The inclusion criteria were: the presence of at least one coronary stenosis, which was either non-diagnostic or of ambiguous clinical significance caused by embedded coronary calcium deposit. Exclusion criteria were uncorrectable motion artifacts on CTCA study, body mass index (BMI) above $40 \mathrm{~kg} / \mathrm{m}^{2}$, atrial fibrillation, previous bypass surgery, and unstable clinical condition. The invasive angiography and intravascular ultrasound (IVUS) was performed on average $43 \pm 37$ days after the CTCA study.

The study protocol was approved by the institutional ethics committee, and all patients gave informed consent to participate.

\section{Computed tomography coronary angiography and intravascular ultrasound}

Computed tomography coronary angiography (CTCA) was performed using a 2 × 64-slice CT scanner (Somatom Def- inition, Siemens Medical Solutions, Forchheim, Germany) after sublingual administration of nitrates $(0.8 \mathrm{mg})$. In cases with a heart rate $\geq 70$ beats/min, an additional intravenous bolus of metoprolol (sequential doses of $5 \mathrm{mg}$, maximal dose $20 \mathrm{mg}$ ) was given. A bolus of $60-80 \mathrm{ml}$ of the contrast agent iomeprol (lomeron 400, Bracco, Italy) was injected intravenously at $6 \mathrm{ml} / \mathrm{s}$. An electrocardiogramgated retrospective acquisition protocol was used in all patients, with 330-ms rotation time, 0.6- $\mathrm{mm}$ collimation, and $100 \mathrm{kV}$ to $120 \mathrm{kV}$ tube voltage. Scan data were reconstructed routinely in mid- to end-diastole $(60 \%$ to $70 \%$ of RR interval) and mid systole (40\% to $50 \%$ of RR interval). Datasets containing motion artifacts were individually optimized by changing the reconstruction window.

Intravascular ultrasound was performed after administration of intracoronary nitroglycerin $(0.2 \mathrm{mg})$. The $20 \mathrm{MHz}$ IVUS catheter (Volcano Corporation, San Diego, California) was advanced to the distal segment of the examined vessel and retrograde imaging was performed with an automatic pullback $(0.5 \mathrm{~mm} / \mathrm{s})$.

\section{Calcium analysis}

A single calcification was defined based on visual assessment of CTCA obtained images, and contained at least one calcium deposit. The calcium deposit was a structure brighter than the surrounding vessel wall tissue that could be visualized separately from the contrast-enhanced coronary lumen either because it was "embedded" within noncalcified plaque or because it was discernible from the contrast-enhanced lumen, visible on contrast CTCA study in at least two independent planes including cross-sectional images and with a density of above $130 \mathrm{HU}$ [7-9]. Separate calcifications were identified if there was at least one boundary transverse cross-section without overlapping calcium deposits. Therefore the single calcification could contain either a single calcium deposit or a series of calcium deposits, as long as they overlapped each other in the longitudinal vessel axis. Within each calcification the minimal lumen area (MLA) cross-section was identified. The lumen areas within the calcified and the reference sites were automatically measured and manually corrected if necessary using Sureplaque $^{T M}$ (ver. 3.9 Toshiba Medical Systems). Since the traditional calcium threshold of $130 \mathrm{HU}$ was inappropriate for quantitative analysis of calcium within the contrastenhanced vessel, we chose a previously validated thresh- 
old of $350 \mathrm{HU}$ for calcium measurements within the contrast-enhanced coronary artery [10, 11]. For IVUS analysis precisely the same MLA and reference sites as selected for the CTCA study were identified based on anatomic landmarks. Off-line IVUS analysis of MLA was performed by a single experienced observer blinded to patients' CTCA measurements.

\section{Statistical analysis}

Continuous data are presented as mean ( \pm standard deviation) and categorical data are reported as frequencies. Student $t$ test and ANOVA were used for comparison of continuous variables as appropriate. Categorical variables were compared using the $\chi^{2}$ test. Pearson's correlation was used for assessment of the relationship between CTCA and IVUS parameters within tertiles. Intraclass correlation coefficient (a method of agreement for continuous variables) was used to assess intraobserver variability in IVUS and CTCA measurements. Bland-Altman plots were produced to visualize the difference between measurements by the imaging techniques. All tests were two-sided. Value of $p<0.05$ was considered statistically significant. All analyses were performed with SPSS 9.0 (SPSS Inc, Chicago, III) or MedCalc 12.3.0.0. (MedCalc Software, Mariakerke, Belgium).

\section{Results}

We evaluated 252 coronary cross-sections within 97 arteries of 60 patients. Clinical characteristics of study patients and the CT scan parameters are presented in Table 1. Intraobserver variability expressed with intraclass correla-

Table 1. Baseline characteristics

Tabela 1. Charakterystyka kliniczna

\begin{tabular}{lc} 
Clinical characteristics & $\begin{array}{c}\text { Prevalence/60 } \\
\text { Mean } \pm \text { SD }\end{array}$ \\
\hline Hyperlipidemia & $55 / 60$ \\
\hline Hypertension & $52 / 60$ \\
\hline Family history of coronary disease & $16 / 60$ \\
\hline Diabetes & $16 / 60$ \\
\hline Smoking & $15 / 60$ \\
\hline Serum creatinine $\left[\mu \mathrm{mol}^{\prime}\right]$ & $87 \pm 19$ \\
\hline Height [cm] & $172 \pm 9$ \\
\hline Weight [kg] & $80 \pm 14$ \\
\hline Body mass index [kg/m²] & $27 \pm 4$ \\
\hline Calcium score & $433 \pm 353$ \\
\hline Scan parameters: \\
kV \\
mA \\
\hline SD - standard deviation \\
\end{tabular}

$S D$ - standard deviation

Table 2. Comparison of the calcium characteristics as assessed with CTCA vs. IVUS

Tabela 2. Porównanie charakterystyki zwapnień w CTCA i IVUS

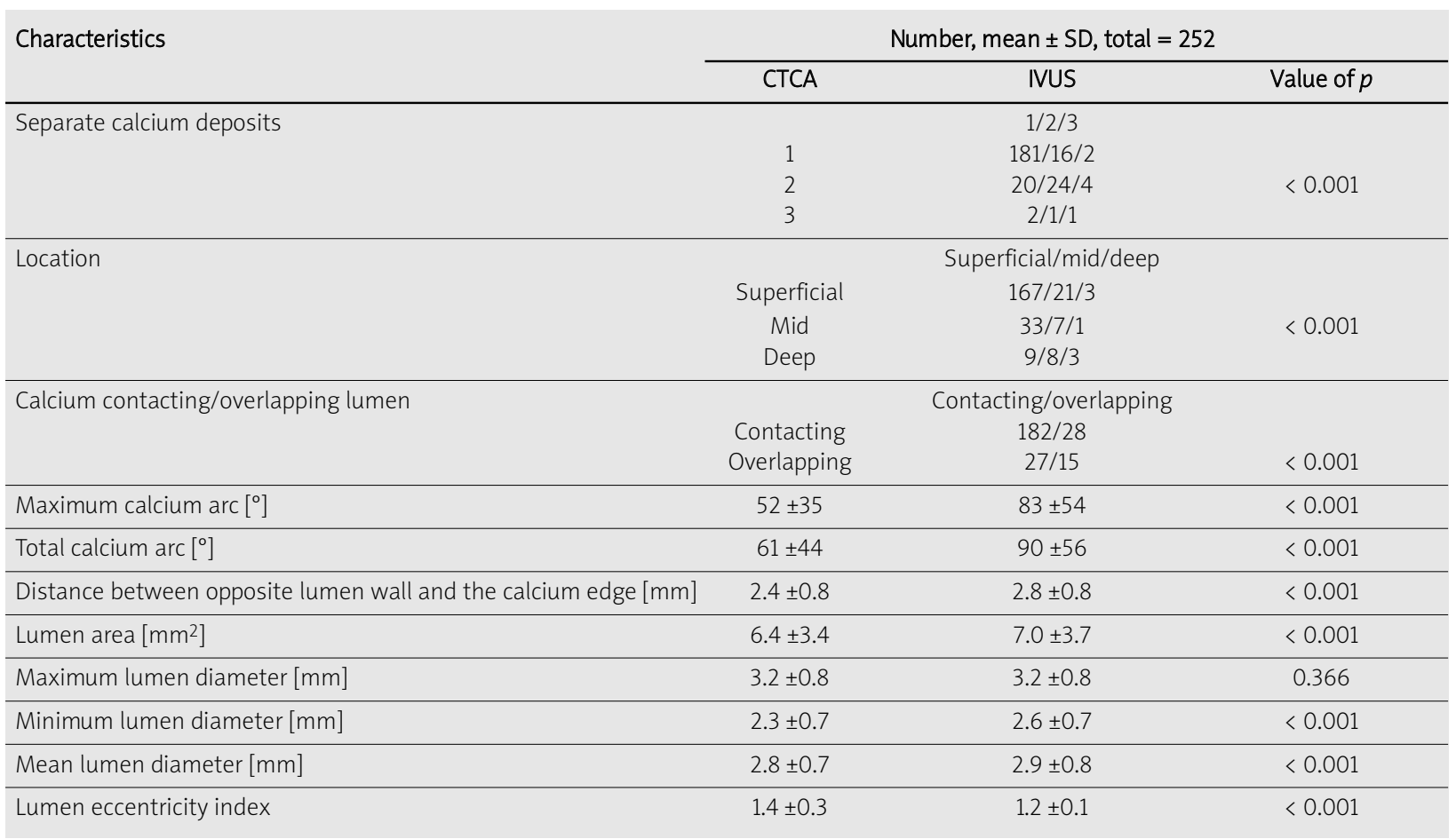

Data presented as means ( \pm standard deviation) and numbers for proportions. Values of $p$ derived from $\chi^{2}$ and Student $t$-test for comparison of categorical and continuous data respectively 

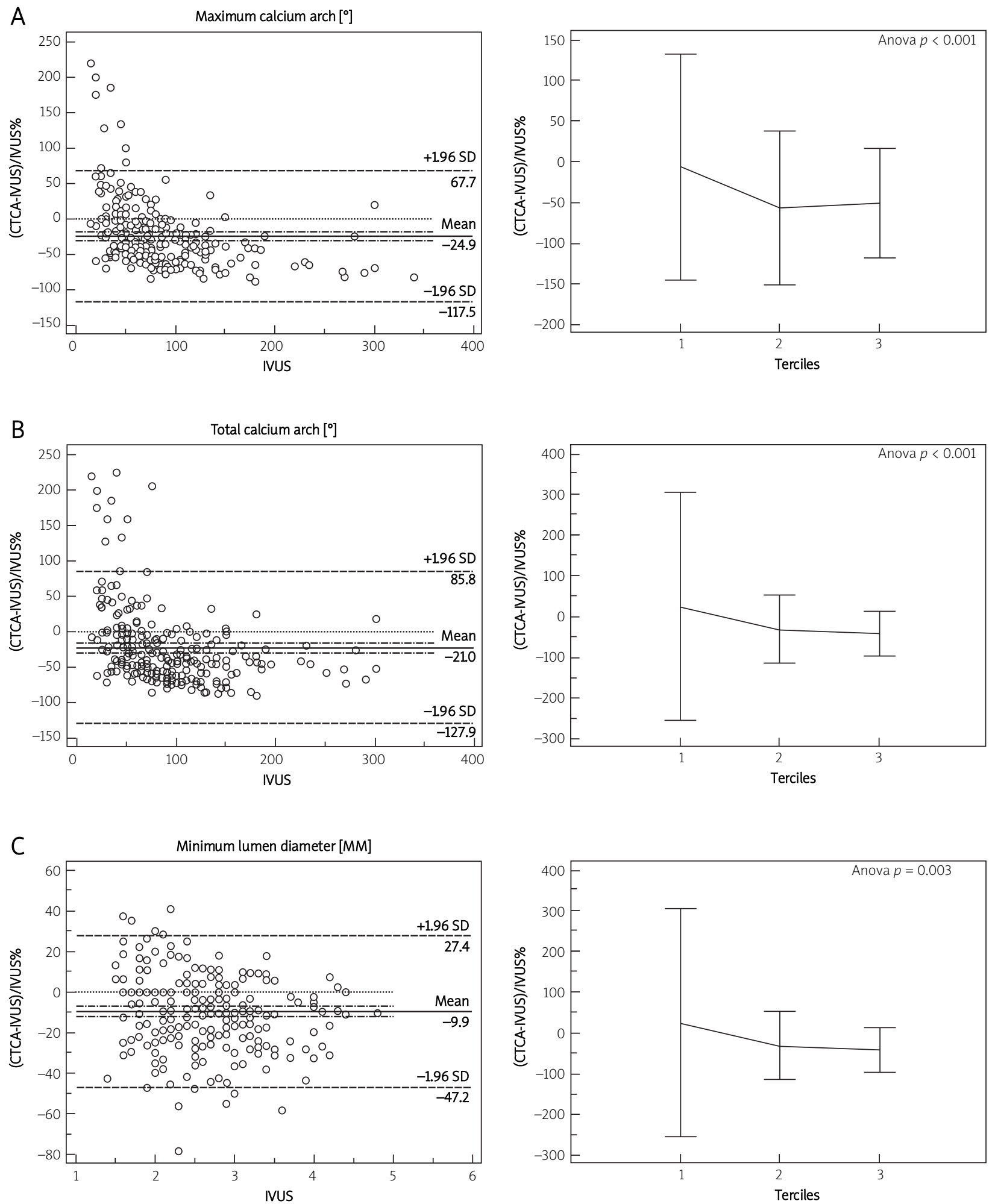

Fig. 1. Bland-Altman plots and comparison of tertiles ( \pm 2 SD) of relative (percent) differences between respective lumen and calcium parameters as assessed by intravascular ultrasound (IVUS) vs. computed tomography coronary angiography (CTCA): A - maximum calcium arch, B - total calcium arch, C-minimum lumen diameter Ryc. 1. Wykresy Bland-Altmana oraz porównanie tercyli ( 2 SD) względnej (\%) różnicy pomiędzy odpowiednimi parametrami światła naczynia i zwapnienia ocenionych w ultrasonografii wewnątrznaczyniowej (IVUS) i tomografii komputerowej (CTCA): $A$ - maksymalny kąt zwapnienia, B - catkowity kąt zwapnienia, $C$ - minimalna średnica światta 

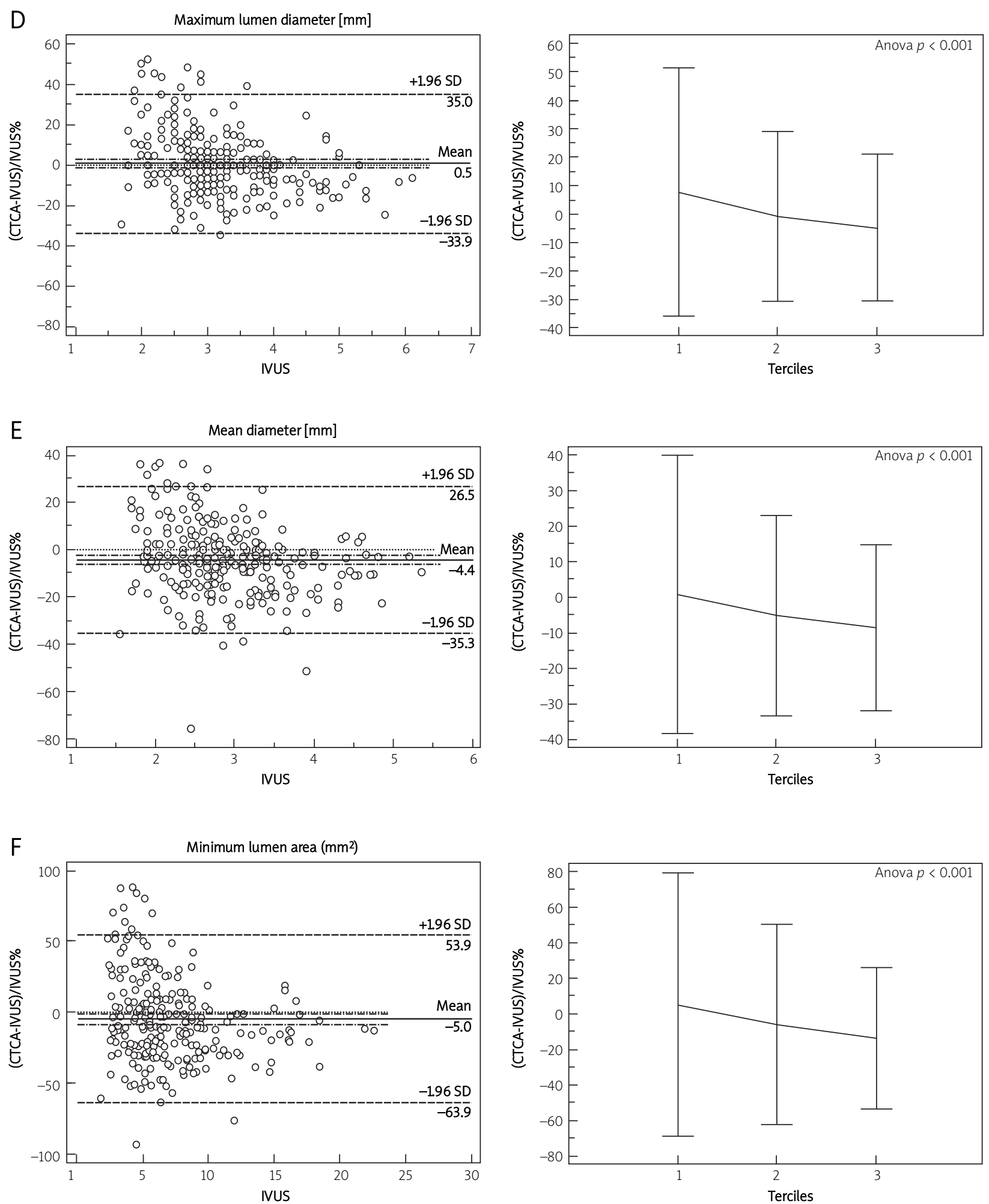

Fig. 1. Continued: D - maximum lumen diameter, $\mathrm{E}$ - mean diameter, $\mathrm{F}$ - minimum lumen area Ryc. 1. Ciag dalszy: $D$ - maksymalna średnica światta, $E$ - uśredniona średnica światta, $F$ - minimalne pole światta naczynia 
G

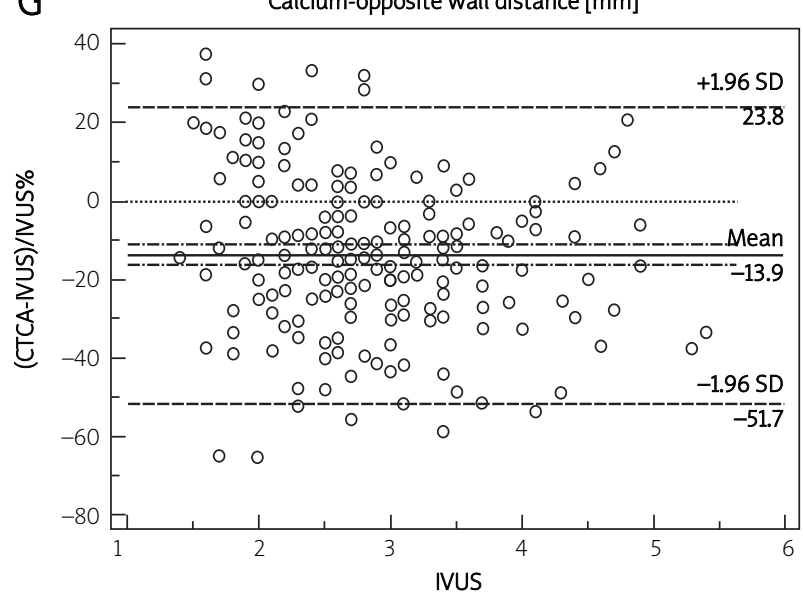

$\mathrm{H}$

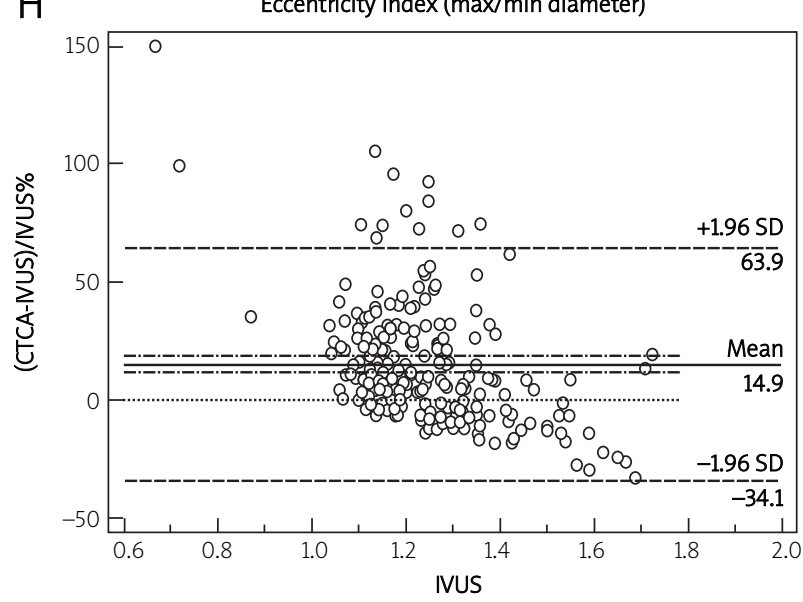

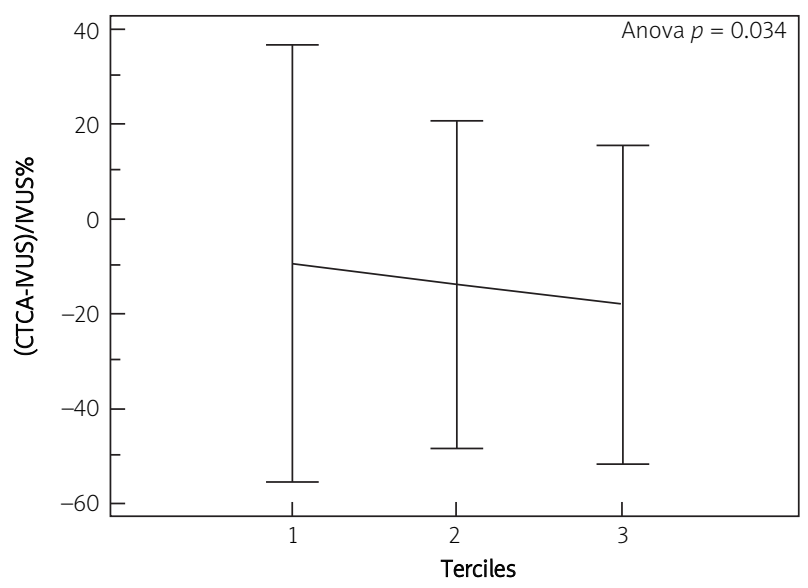

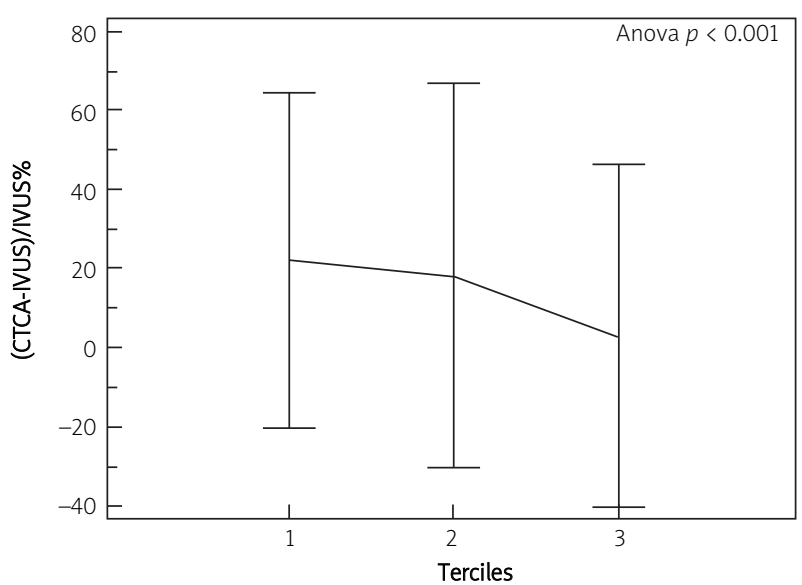

Fig. 1. Continued: $\mathrm{G}$ - calcium-opposite wall distance, $\mathrm{H}$ - eccentricity index

Ryc. 1. Ciąg dalszy: $G$ - odległość między zwapnieniem i przeciwna ściana, $H$-średnica maks./min.

tion coefficients for assessment of minimum lumen area was up to 0.99 for IVUS measurements, and up to 0.97 for DSCT measurements (the same cross-sections assessed more than 6 weeks apart).

Comparison of coronary lumen and calcium characteristics between CTCA and IVUS images is presented in Table 2. Significant differences were observed for all of the parameters except the maximum lumen diameter. There was a significant discrepancy in ability to recognize multiple calcium deposits, or calcium location between CTCA and IVUS. In 27 (11\%) cases CTCA analysis failed to reveal calcium deposits contacting the lumen. CTCA-based calcium and lumen analysis significantly underestimated calcium arc (both total and maximum), minimum and mean lumen diameters, lumen area and the distance between the opposite lumen wall and the calcium edge (Figure 1).

Analysis of differences between CTCA and IVUS within tertiles of the examined parameters revealed that significant calcium arc underestimation by CTCA was present only within calcifications with a more extensive $\operatorname{arc}\left(2^{\text {nd }}\right.$ and $3^{\text {rd }}$ tertiles). The minimum lumen diameter and the distance between the opposite wall and calcium were underestimated by CTCA within all the tertiles. The maximum lumen diameter was overestimated by CTCA within the lowest values (1st tertile) and underestimated within the $3^{\text {rd }}$ tertile. Subsequently, mean lumen diameter was underestimated by CTCA within the $2^{\text {nd }}$ and $3^{\text {rd }}$ tertiles. Minimum lumen area did not differ significantly for the lowest values but was underestimated by CTCA within the $2^{\text {nd }}$ and $3^{\text {rd }}$ tertiles. The eccentricity index was higher as assessed with CTCA for less eccentric lesions (1st and $2^{\text {nd }}$ tertiles) (Figure 1, Table 3).

\section{Discussion}

Our data indicate a significant discrepancy between CTCA and IVUS in assessment of calcified coronary lesions. The discrepancies regard both the lumen and the calcium dimensions, and are dependent on the size of these structures. 
Table 3. Comparison of the calcium characteristics within their tertiles as assessed with CTCA versus IVUS

Tabela 3. Porównanie charakterystyki zwapnień w CTCA i w IVUS w obrębie tercyli

\begin{tabular}{|c|c|c|}
\hline IVUS characteristics & Tertiles, mean (range) for $1^{\text {st }} / 2^{\text {nd }} / 3^{r d}$ & $\begin{array}{l}\text { Value of } p \text { for difference between } \\
\text { CTCA vs. IVUS within } 1^{\text {st } / 2^{\text {nd }} / 3^{\text {rd }} \text { tertiles }}\end{array}$ \\
\hline Maximum calcium $\operatorname{arc}\left[{ }^{\circ}\right]$ & $40(15-55) / 70(56-85) / 139(86-360)$ & $0.537 /<0.001 /<0.001$ \\
\hline Total calcium $\operatorname{arc}\left[{ }^{\circ}\right]$ & $40(15-56) / 79(58-105) / 155$ (110-360) & $0.265 /<0.001 /<0.001$ \\
\hline $\begin{array}{l}\text { Distance between opposite lumen } \\
\text { wall and the calcium edge [mm] }\end{array}$ & $2.0(1.4-2.3) / 2.7(2.4-3.0) / 3.7(3.10-5.40)$ & $0.001 /<0.001 /<0.001$ \\
\hline Lumen area $\left[\mathrm{mm}^{2}\right]$ & $3.7(1.8-5.0) / 6.0(5.10-7.60) / 11.2(7.70-22.50)$ & $0.264 / 0.042 /<0.001$ \\
\hline Maximum lumen diameter [mm] & $2.4(1.7-2.7) / 3.0(2.8-3.3) / 4.1(3.4-6.10)$ & $0.004 / 0.495 /<0.001$ \\
\hline Minimum lumen diameter [mm] & $1.9(1.4-2.2) / 2.5(2.3-2.8) / 3.4(2.9-4.8)$ & $0.024 /<0.001 /<0.001$ \\
\hline Mean lumen diameter [mm] & $2.1(1.6-2.5) / 2.8(2.6-3.1) / 3.8(3.2-5.4)$ & $0.528 / 0.001 /<0.001$ \\
\hline Lumen eccentricity index & $1.11(1.00-1.16) / 1.21(1.17-1.27) / 1.39(1.28-1.72)$ & $<0.001 /<0.001 / 0.277$ \\
\hline
\end{tabular}

Coronary calcifications are a major source of stenosis overestimation by CTCA as compared to ICA ( $94 \%$ of false-positive findings) [4]. According to Brodoefel et al. calcifications are the single factor impacting diagnostic accuracy of CTCA [5]. It has also been shown that obstructive coronary artery disease is least accurately diagnosed within large calcifications as opposed to moderate or small ones [2]. Of quantitative calcium parameters, calcium arc above $90^{\circ}$ has been shown to correlate with stenosis overestimation by CTCA [6]. However, coronary calcifications may also be associated with stenosis underestimation by CTCA. According to a study of Hoffman et al., calcifications may be responsible for $14 \%$ of false-negative findings [4]. In another study, stenosis underestimation has been reported in $6 \%$ of mild and $8 \%$ of more severe calcifications [6].

According to our data, the mean lumen diameter and the minimum lumen area measured on CTCA did not differ significantly from values obtained with IVUS for small lumens; it was in larger vessels (range: $5.10-22.50 \mathrm{~mm}^{2}$ ) that CTCA significantly and systematically underestimated lumen area. These results, especially the lack of significant bias in assessment of mean lumen diameter and lumen area within the smallest lumens/vessels (mean MLA: $3.7 \mathrm{~mm}^{2}$ ), seem counterintuitive in the context of the previously cited data. Our results however provide further insight, by showing significant (above 70\%) scatter of the lumen area measurements within these smallest lumens. The CTCA measurements deviate from IVUS significantly less within the larger vessels. Such data suggest that diagnostic errors in assessment of calcified lesions on CTCA may be partially attributed to the general inaccuracy of CTCA in measurement of smaller lumens (on the verge of significance), secondary to inadequate CTCA spatial resolution (Figure 1). In such circumstances, additional image disturbances caused by even small calcifications may turn into significant diagnostic errors.

Since in some cases CTCA significantly underestimated calcium arc and overestimated the distance between the opposite lumen wall and the calcium, contrary to the established paradigm, partial volume artifact with resulting blooming is unlikely to be the sole source of inaccuracy of CTCA in calcified lesions. Previous data indicate that around half of coronary calcifications may be missed on CTCA [10]. In $11 \%$ of our cases CTCA failed to reveal calcium deposits contacting the lumen. It is therefore likely that in some cases of less dense, superficial calcifications, they may be merged with the coronary lumen on CTCA derived images, leading to lumen overestimation.

Methods applied for our analysis differ significantly from all of the previous studies exploring the relationship between calcifications and diagnostic accuracy of CTCA, which relied on the suboptimal reference of invasive angiography [12-15]. Invasive angiography does not provide optimal stenosis assessment within ostia or bifurcations (a frequent site of coronary calcifications), mainly due to the limited number of projections [12-15]. Also, calcified lesions may present with a filling defect, preempting accurate stenosis assessment on angiography [16, 17]. Application of IVUS as the reference study corrected for these limitations and allowed us to obtain unprecedented data.

The results of our study have several implications. First of all, the bi-directional, significant scatter of measurements, in particular within small (mean MLA: $3.7 \mathrm{~mm}^{2}$ ) calcified lumens, suggests caution with definite stenosis categorization in these patients based on CTCA. This is particularly important due to frequently observed lumen overestimation, posing a risk of missing significant stenoses. Our findings refer also to emerging methods of non-invasive assessment of fractional flow reserve. Since the minimum lumen area within stenosis is exponentially related to its resistance, even small deviation of measurements from the true dimensions may translate into significant, qualitative diagnostic error. This may likely explain the recent disappointing results of the deFacto study [18]. Our data also suggest that technology development required to improve assessment of calcified lesions should be aimed not only 
at the correction of blooming but primarily at improvement of spatial resolution.

Contemporary CTCA technology applied for assessment of coronary artery disease has several limitations referring to assessment of coronary calcifications. These include suboptimal spatial resolution, and susceptibility to blooming artifacts. Although it is impossible to fully make up for these constraints, in this analysis we used the least subjective data derivation methods possible based on semi-automated SurePlaque ${ }^{\mathrm{TM}}$ software. Subsequently, the reference method of IVUS may be useful for provision of lumen and selected calcium parameters; however, due to acoustic signal shadowing it was impossible to compare calcium thickness or other volumetric calcium parameters, which could possibly provide further important information.

\section{Conclusions}

Assessment of calcified coronary arteries by CTCA is least accurate within small coronary lumens, already on the verge of physiological significance. In these circumstances even relatively minute lumen measurement disturbances caused by calcifications may lead to significant qualitative diagnostic errors.

\section{Acknowledgments}

Supported with a grant of the Polish Ministry of Science, number N N402 296436.

We thank Lukas Skibiński of Toshiba Poland for excellent assistance and unrestricted access to a Vitrea workstation with SurePlaque ${ }^{\mathrm{TM}}$ software.

\section{References}

1. Taylor AJ, Cerqueira M, Hodgson JM, et al. ACCF/SCCT/ACR/ AHA/ASE/ASNC/NASCI/SCAI/SCMR 2010 appropriate use criteria for cardiac computed tomography. A report of the American College of Cardiology Foundation Appropriate Use Criteria Task Force, the Society of Cardiovascular Computed Tomography, the American College of Radiology, the American Heart Association, the American Society of Echocardiography, the American Society of Nuclear Cardiology, the North American Society for Cardiovascular Imaging, the Society for Cardiovascular Angiography and Interventions, and the Society for Cardiovascular Magnetic Resonance. J Am Coll Cardiol 2010; 56: 1864-1894.

2. Zhang S, Levin DC, Halpern EJ, et al. Accuracy of MDCT in assessing the degree of stenosis caused by calcified coronary artery plaques. Am J Roentgenol 2008; 191: 1676-1683.

3. Raff GL, Gallagher MJ, O'Neill WW, Goldstein JA. Diagnostic accuracy of noninvasive coronary angiography using 64-slice spiral computed tomography. J Am Coll Cardiol 2005; 46: 552-557.

4. Hoffmann U, Moselewski F, Cury RC, et al. Predictive value of 16slice multidetector spiral computed tomography to detect significant obstructive coronary artery disease in patients at high risk for coro- nary artery disease: patient-versus segment-based analysis. Circulation 2004; 110: 2638-2643.

5. Brodoefel H, Burgstahler C, Tsiflikas I, et al. Dual-source CT: effect of heart rate, heart rate variability, and calcification on image quality and diagnostic accuracy. Radiology 2008; 247: 346-355.

6. Vavere AL, Arbab-Zadeh A, Rochitte CE, et al. Coronary artery stenoses: accuracy of 64-detector row CT angiography in segments with mild, moderate, or severe calcification: a subanalysis of the CORE-64 trial. Radiology 2011; 261: 100-108.

7. Sun J, Zhang Z, Lu B, et al. Identification and quantification of coronary atherosclerotic plaques: a comparison of 64-MDCT and intravascular ultrasound. AJR Am J Roentgenol 2008; 190: 748-754.

8. Achenbach S, Moselewski F, Ropers D, et al. Detection of calcified and noncalcified coronary atherosclerotic plaque by contrastenhanced, submillimeter multidetector spiral computed tomography: a segment-based comparison with intravascular ultrasound. Circulation 2004; 109: 14-17.

9. Bauer RW, Thilo C, Chiaramida SA, et al. Noncalcified atherosclerotic plaque burden at coronary $\mathrm{CT}$ angiography: a better predictor of ischemia at stress myocardial perfusion imaging than calcium score and stenosis severity. AJR Am J Roentgenol 2009; 193: 410-418.

10. van der Giessen AG, Gijsen FJ, Wentzel JJ, et al. Small coronary calcifications are not detectable by 64-slice contrast enhanced computed tomography. Int J Cardiovasc Imaging 2011; 27: 143-152.

11. Hong C, Becker CR, Schoepf UJ, et al. Coronary artery calcium: absolute quantification in nonenhanced and contrast-enhanced multi-detector row CT studies. Radiology 2002; 223: 474-480.

12. Okabe T, Weigold WG, Mintz GS, et al. Comparison of intravascular ultrasound to contrast-enhanced 64-slice computed tomography to assess the significance of angiographically ambiguous coronary narrowings. Am J Cardiol 2008; 102: 994-1001.

13. Joshi SB, Okabe T, Roswell RO, et al. Accuracy of computed tomographic angiography for stenosis quantification using quantitative coronary angiography or intravascular ultrasound as the gold standard. Am J Cardiol 2009; 104: 1047-1051.

14. Caussin C, Larchez C, Ghostine S, et al. Comparison of coronary minimal lumen area quantification by sixty-four-slice computed tomography versus intravascular ultrasound for intermediate stenosis. Am J Cardiol 2006; 98: 871-876.

15. Dragu R, Kerner A, Gruberg L, et al. Angiographically uncertain left main coronary artery narrowings: correlation with multidetector computed tomography and intravascular ultrasound. Int J Cardiovasc Imaging 2008; 24: 557-563.

16. Duissaillant GR, Mintz GS, Pichard AD, et al. Intravascular ultrasound identification of calcified intraluminal lesions misdiagnosed as thrombi by coronary angiography. Am Heart J 1996; 132: 687-689.

17. Kotani J, Mintz GS, Rai PB, et al. Intravascular ultrasound assessment of angiographic filling defects in native coronary arteries: do they always contain thrombi? J Am Coll Cardiol 2004; 44: 2087-2089.

18. Min JK, Leipsic J, Pencina MJ, et al. Diagnostic accuracy of fractional flow reserve from anatomic CT angiography. JAMA 2012; 308: 1237-1245. 